\title{
The Gut Peptide Hormone Family, Motilin and Ghrelin
}

\author{
Ichiro Sakata and Takafumi Sakai \\ Saitama University \\ Japan
}

\section{Introduction}

Endocrine hormones are a system of glands, each of which secretes a type of hormone into the bloodstream to regulate multiple physiology of the body. In the past several decades, many hormones from the gastrointestinal tract has been identified and cloned, and their physiological functions have been studied. Although the pituitary gland was considered to be the main endocrine organ of the body in early studies, there are other organs that produce endocrine hormones such as adipose tissue, reproductive organ, adrenal gland, and gastrointestinal tract. Among those, the gastrointestinal tract is the largest endocrine organ of the body in volume, and hormones produced in the gastrointestinal tract are physiologically important for their roles in development, growth, cardiovascular, gastric motility, behavior and maintenance of energy homeostasis. Many hormones have been identified in each different parts of the gastrointestinal tract. For instance, in the stomach, gastrin, histamine (Dornonville de la Cour, et al. 2001), somatostatin (Bolkent, et al. 2001), neuropeptide Y (Wang, et al. 1987), ghrelin (Sakata, et al. 2002) and leptin (Bado, et al. 1998) are produced in the mucosal layer and/or myentric plexus, and cholecystokinin (CCK) (Miyamoto and Miyamoto 2004), glucagon-like peptide-1 (Theodorakis, et al. 2006), motilin (Sakai, et al. 1994a) (Satoh, et al. 1995), serotonin (Ku, et al. 2004) and PYY $Y_{3-36}$ (Rozengurt, et al. 2006) are produced in the upper and lower intestine. Motilin and ghrelin are considered to comprise a peptide family based on similarity of their structures and also their similarity in each specific $G$ protein coupled receptor, growth hormone secretagogue receptor (GHS-R) and motilin receptor (MTL-R, also known as GPR38). In this chapter, we review recent research and knowledge of the peptides, motilin and ghrelin regarding their structures, distribution of motilin- and ghrelin-producing cells, distribution of their receptors, plasma profies and secretion of motilin and ghrelin, and the role of motilin and ghrelin in gastric motility. However, there is a lack of basic information for motilin study such as information on the detailed distribution of motilin and motilin receptor in the body and changes in motilin release under some physiological states. One of the reasons for the difficulty in motilin study is that rodents such as rats and mice cannot be used for motilin study because the motilin gene is inactivated in the common ancestor of mice and rats (He, et al. 2010). For this reason, motilin has been studied using relatively large- sized animals, such as dogs and rabbits, which has made it difficult to investigate in detail the mechanisms underlying the actions of motilin. Recently, we characterized the house musk shrew (Suncus murinus, order: Insectivora, suncus named as laboratory strain) as a motilin- and ghrelin-producing small 
animal model for studies on gastric motility, and we therefore also provide some information on suncus motilin and ghrelin.

\section{Structures of motilin and ghrelin}

Motilin was initially isolated from a side fraction produced during the purification of secretin by Brown et al. in 1971 (Brown, et al. 1971), and the complete amino acid sequence of motilin was determined in 1973 (Brown, et al. 1973). Mature motilin is a 22-amino-acid polypeptide with a molecular weight of 2698 , and motilin has been isolated from humans (Strausberg, et al. 2002), pigs (Khan, et al. 1990) (Bond, et al. 1988), dogs (Ohshiro, et al. 2008), cats (Xu, et al. 2003), guinea pigs (Xu, et al. 2001), rabbits (Banfield, et al. 1992), and chickens (De Clercq, et al. 1996). We recently identified and cloned suncus motilin as a useful small animal model, and the mature region of suncus motilin is highly conserved between these species (Tsutsui, et al. 2009). The precursor of motilin consists of 133 amino acids and includes a 25-amino-acid signal peptide followed by a 22-amino-acid motilin sequence and a motilin-associated peptide (MAP) (Banfield et al. 1992). The amino acid sequence of MAP is also conserved between species, but the functional and physiological roles of MAP have not been elucidated.

Ghrelin was identified from rat and human stomach extracts by Kojima et al. in 1999 using a "reverse pharmacology" strategy (Kojima, et al. 1999). In mice, rats and humans, ghrelin is a 28-amino-acids polypeptide and, interestingly, ghrelin has an acyl modification at the third serine by $n$-octanoate, one of the medium chain fatty acids (Kojima et al. 1999). Ghrelin exists as two different molecular forms, acyl ghrelin (modified form) and des-acyl ghrelin (unmodified form), in both gastric ghrelin-producing cells and circulation (Ariyasu, et al. 2001; Fujimiya, et al.). Ghrelin has been identified in many species, including mammlas, avians (Kaiya, et al. 2002; Wada, et al. 2003), amphibians (Kaiya, et al. 2001; Kaiya, et al. 2006), reptilian (Kaiya, et al. 2004), and fish (Kaiya, et al. 2009; Kaiya, et al. 2003; Miura, et al. 2009), and the sequence of first seven amino acids of the N-terminal region of ghrelin are highly conserved between species (Kojima, et al. 2008). In addition, it has been reported that the first four or five amino acids are sufficient for calcium mobilization in vitro (Bednarek, et al. 2000).

\section{Distributions of motilin- and ghrelin-producing cells}

The distribution of motilin-producing cells in the gastrointestinal tract has been studied by using immunohistochemistry and in situ hybridization techniques. Since motilin is genetically knockdown in rats and mice, the distribution and morphology of motilinproducing cells were investigated using rabbits (Satoh et al. 1995), monkeys, and humans (Helmstaedter, et al. 1979). In rabbits, motilin-immunopositive cells were found in the epithelia of the crypts and villi throughout the gastrointestinal tract from the gastric antrum to the distal colon, but no immunostaining was observed in the gastric body (Satoh et al. 1995), and motilin-producing cells were localized abundantly in the upper small intestine. Cell densities (cells $/ \mathrm{mm}^{2}$, mean $\pm \mathrm{SE}$ ) were $0.41 \pm 0.16$ in the gastric antrum, $8.2 \pm 0.8$ in the duodenum, $1.9 \pm 0.5$ in the jejunum, $0.62 \pm 0.14$ in the ileum, $0.19 \pm 0.05$ in the cecum, $0.13 \pm$ 0.03 in the proximal colon, and $0.39 \pm 0.18$ in the distal colon (Satoh et al. 1995). Immunoelectron microscopic observations revealed that the motilin-producing cell is characterized by relatively small $(180 \mathrm{~nm}$ in man; $200 \mathrm{~nm}$ in the dog) solid granules with a homogeneous core and closely applied membrane, round in man and round to irregularly- 
shaped in the dog. Recently, we succeeded in identification of suncus motilin cDNA and amino acid sequence (Tsutsui et al. 2009), and immunohistochemical analysis was performed in all regions of the gastrointestinal tract and also in situ hybridization analysis was performed to detect motilin mRNA-expressing cells. Motilin-immunopositive and expressing cells in suncus were observed in the mucosal layer but not in the myenteric plexus and were abundantly distributed in the upper intestine. However, the density of motilin mRNA-expressing cells was slightly higher than that of motilin-immunopositive cells, suggesting low accumulation of motilin in the cytoplasm. In addition, motilinproducing cells in suncus were closed- and opened-type cells as previously reported in other mammals.

Gastric ghrelin cells had been classified as X/A-like cells by their round, compact, electrondense secretory granules that distinguish them electron-microscopically from other previously characterized gastric endocrine cell types before the discovery of ghrelin (Dornonville de la Cour et al. 2001) (Date, et al. 2000). The distribution of ghrelin-producing cells in the gastrointestinal tract has been studied in many species. Ghrelin-producing cells were most dense in the gastric body and were found in the mucosal layer but not in the myenteric plexus in all of the examined regions of rats (Sakata et al. 2002). In the stomach, most of the ghrelin cells were observed in the glandular base to body of the fundic gland, and a few ghrelin cells were observed in the glandular neck. In rodents, in addition to the stomach, ghrelin-producing cells were observed in all regions of the gastrointestinal tract, including the duodenum, ileum, cecum and colon (Sakata et al. 2002). In the duodenum, ileum, cecum and colon, ghrelin cells were scattered in the epithelia of crypts and villi, and the densities of ghrelin cells were dramatically decreased toward the lower gastrointestinal tract. In the stomach, ghrelin-producing cells were observed as small and round-shaped cells (called closed-type cells). On the other hand, in the duodenum, ileum, cecum and colon, ghrelin cells were found as two different types of endocrine cells, closed-type cells with triangular or elongated shapes and opened-type cells with their apical cytoplasmic process in contact with the lumen. In suncus, ghrelin-producing cells were abundant in the stomach and most of the ghrelin cells were closed-type cells with relatively rich cytoplasm and scattered in the glandular body and base of the gastric mucosa (Ishida, et al. 2009). Using electron microscopic observation, immunogold labeling for ghrelin has been shown to be localized on round and electron-dense granules in gastric mucosal cells. The diameters of granules containing ghrelin in mice $(277.7 \pm 11.1 \mathrm{~nm})$ and rats $(268.8 \pm 13.0 \mathrm{~nm})$ were similar; however, those in hamsters $(200.8 \pm 8.8 \mathrm{~nm})$ were significantly smaller than those in mice or rats. Rindi et al. demonstrated that mouse and canine ghrelin-immunoreactive cells closely resembled those of the human stomach, though it has been shown that dog ghrelin cells have obviously larger granules $(273 \pm 49 \mathrm{~nm})$ than those of rats $(183 \pm 37 \mathrm{~nm})$ and humans $(147 \pm 30 \mathrm{~nm})$.

Co-localization of motilin and ghrelin was examined in the human biopsy and tissues from pig by immunohistochemistry and in situ hybridization in a study by Wierup et al. (Wierup, et al. 2007). They showed that ghrelin and motilin are coproduced in the same cells in the duodenum and jejunum of humans and pigs and that ghrelin and motilin are stored in all secretory granules of such cells in humans, suggesting that motilin and ghrelin are cosecreted by the same stimulus (Wierup et al. 2007). As mentioned above, suncus is a small laboratory animal that produces both motilin and ghrelin, and further studies are therefore needed to examine the co-localization of motilin and ghrelin in the duodenum and lower intestine of suncus. 


\section{Distributions of motilin and ghrelin receptors}

The receptor for motilin was identified from the human gastrointestinal tract by Feighner et al. in 1999 (Feighner, et al. 1999) and it is now called GPR38 or motilin receptor. Growth hormone secretagogue receptor (GHS-R) was initially identified from the pituitary gland and brain in 1996 (Howard, et al. 1996), and GHS-R had been known as the orphan receptor until ghrelin was discovered. In the process of exploring the natural ligand for the GHS-R using reverse pharmacology, ghrelin was discovered as an endogenous ligand for GHS-R. Both motilin and ghrelin receptors belong to the seven transmembrane $G$ protein-coupled receptor family (McKee, et al. 1997), and these receptors showed high sequence homology of $52 \%$ to each other in humans (Takeshita, et al. 2006). The tissue distribution of motilin and ghrelin receptors has been mainly examined using binding assays or mRNA analysis with RT-PCR. Motilin binding sites were found on smooth muscle layers of the gastric antrum, duodenum and colon, but no positive binding reaction was detected in the smooth muscle layer of the cecum (Sakai, et al. 1994b). Specific binding sites were particularly abundant in the circular muscle layers, with low concentrations in longitudinal muscle layers of the gastric antrum, duodenum and colon, and no motilin binding sites were found in the mucosa of the gastrointestinal tract and pancreas (Sakai et al. 1994b). mRNA analysis showed that motilin receptor was expressed in the gastrointestinal tract in humans (Takeshita et al. 2006; Ter Beek, et al. 2008), dogs (Ohshiro et al. 2008), guinea pigs (Xu, et al. 2005) and chickens (Yamamoto, et al. 2008). It has also been shown that motilin receptor immunoreactivity was present in muscle cells and the myenteric plexus, but not in mucosal or submucosal cells in humans (Takeshita et al. 2006). In dogs, motilin receptor immunoreactivity was observed among muscle fibers on both the longitudinal and circular muscle layers (Ohshiro et al. 2008). In the guinea pig stomach, motilin receptor immunoreactivity was also found in the myenteric plexus, consistent with findings in humans and dogs (Xu et al. 2005). In addition to gastrointestinal tract, Depoortere et al. reported that specific binding sites for the motilin receptor were observed in the hippocampus, thalamus, hypothalamus and amygdaloid body in the central nervous system (Depoortere, et al. 1997).

On the other hand, distribution of the ghrelin receptor (GHS-R) has been studied in detail in several species, and it has been shown that the ghrelin receptor is expressed widely in the body from the central nervous system to peripheral organs. In rodents, expression of ghrelin receptor mRNA was observed in the various of regions of the brain, with high expression levels in Arcuate nucleus (Arc), Ventromedial nucleus, Ventral tegmental area (VTA), hippocampus and the nucleus of solitary tract (NTS) (Zigman, et al. 2006) (Mondal, et al. 2005) (Guan, et al. 1997). In addition, high expression levels of GHS-R were found in the pituitary gland (Kamegai, et al. 2001) (Gnanapavan, et al. 2002) and pancreas (Kageyama, et al. 2005) (Volante, et al. 2002). In the gastrointestinal tract, ghrelin receptor mRNA expression was also found throughout the stomach and intestines, and expression of the ghrelin receptor was detected in the muscle layer but not in the mucosal layer in the stomach (Date et al. 2000). Moreover, it has been reported that ghrelin receptor immunoreactivity was found within neuronal cell bodies and fibers in rats (Dass, et al. 2003) and that ghrelin receptor mRNA transcripts were found in longitudinal muscle/myenteric plexus preparations and in cultured myenteric neurons of the guinea pig (Xu et al. 2005)

\section{Roles of motilin and ghrelin in gastric motility}

According to the origin of its name, the main function of motilin is to stimulate gastric motility. Migrating motor complex (MMC) is characterized by the appearance of 
gastrointestinal motility in the interdigestive state. It has been reported that these coordinated contractions consist of three phases, phase I (period of motor quiescence), phase II (period of preceding irregular contractions) and phase III (period of clustered potent contractions). It has been shown that plasma concentration of motilin changed in a cyclic fashion and that it has rhythmus occurring every 90-100 min. In fact, administration of motilin has been shown to induce phase III-like contraction via the cholinergic pathway, and endogenous motilin is thought to be physiologically important for phase III contraction (Vantrappen, et al. 1979) (Itoh, et al. 1978).

Since the ghrelin receptor is expressed in the gastrointestinal tract, the effect of ghrelin on gastric motility has also been examined. In rats, ghrelin exerts stimulatory effects on motility of the antrum and duodenum in both fed and fasted states (Fujimiya, et al. 2008), and Taniguchi et al. reported that ghrelin infusion significantly increased motility index of phase III-like contractions at the antrum and jejunum in a dose dependent manner (Taniguchi, et al. 2008). As well as the rat stomach, phase III-like contractions in mice were observed in the interdigestive state, and no spontaneous phase III-like contractions were found in vagotomized mice, suggesting that ghrelin-induced gastric phase III-like contractions are mediated via vagal cholinergic pathways in mice (Zheng, et al. 2009). In humans, administration of ghrelin induced a premature gastric phase III of the MMC, which was not mediated through release of motilin (Tack, et al. 2006).

As a new model to study gastric motility, we established an in vitro and in vivo functional assay system using suncus. Administration of suncus motilin showed almost the same contractile effect as that of human motilin in vitro (Tsutsui et al. 2009). During the fasted state, the suncus stomach and duodenum showed clear migrating phase III contractions (intervals of 80-150 $\mathrm{min}$ ) as found in humans and dogs, and motilin injection also increased the gastric motility index in a dose-dependent manner (Sakahara, et al. 2010). Moreover, pretreatment with atropine completely abolished the motilin-induced gastric phase III contractions (Sakahara et al. 2010). Since suncus has almost the same GI motility and motilin response as those found in humans and dogs, suncus would be a suitable model to analyze the interaction of motilin and ghrelin in gastric motility.

\section{Plasma profiles and secretion of motilin and ghrelin in the gastrointestinal tract}

Motilin is mainly produced in the duodenum and secreted into the blood stream. During the interdigestive state, it was found that plasma motilin concentration increased in complete accordance with the cyclical interdigestive contractions of the stomach in dogs (Itoh et al. 1978). Furthermore, plasma motilin concentration was lowered by ingestion of food, and it remained low as long as the gastric motor activity was in the digestive pattern (Itoh et al. 1978). It has been demonstrated that plasma motilin is released at about 100-min intervals in the interdigestive state in humans (Vantrappen et al. 1979) and dogs (Itoh et al. 1978). Zietlow et al. also reported that the peak of plasma motilin levels was always observed in the period of gastric phase III contractions (Zietlow, et al. 2010).

Inverse correlations were found between plasma motilin concentration and glucose and between motilin concentration and insulin, suggesting that glucose and/or insulin are important in suppressing motilin secretion during feeding (Funakoshi, et al. 1985). Dopamine infusion caused a significant decline of plasma motilin levels, and dopamine antagonism with domperidone caused a significant elevation of motilin (Funakoshi, et al. 
1983). Atropine suppressed the basal levels of motilin but did not alter the increment of motilin levels after domperidone administration, suggesting that dopaminergic mechanisms exert a tonic inhibitory effect on motilin secretion in normal subjects (Funakoshi et al. 1983). Using an enzymatic method, dispersed cells from the canine duodenojejunal mucosa were separated by centrifugal counterflow elutriation to enrich motilin content, and carbachol dose-dependently stimulated the release of motilin from its enriched cells (Poitras, et al. 1993). Moreover, bombesin, morphine, and erythromycin stimulated motilin release in vivo, but did not influence the secretion of motilin in vitro (Poitras et al. 1993). Serotonin, GIP, CCK, pentagastrin, cisapride, neosynephrine, isoproterenol, and muscimol also had no effect on motilin release in an in vitro model (Poitras et al. 1993). The response to carbachol was abolished by atropine but was not affected by somatostatin, serotonin, secretin, CCK, or GIP (Poitras et al. 1993). These results suggest that muscarinic receptors are present on the motilin cell membrane and that acetylcholine is a major regulator of motilin release.

It is well known that the stomach is a major source of circulation plasma ghrelin, and the levels were elevated in a fasting state and returned to basal levels after re-feeding (Cummings, et al. 2001; Cummings, et al. 2002). In contrast, peptide content of ghrelin in the stomach decreased after fasting, indicating that cytoplasmic ghrelin released from gastric ghrelin cells caused an increase in plasma ghrelin levels (Toshinai, et al. 2001). The effects of nutrients on ghrelin release have been studied in detail. Oral and intravenous glucose administration sharply reduced plasma ghrelin concentration in rodents, and this effect of glucose on ghrelin inhibition was similar to that found in humans (Broglio, et al. 2004; Soriano-Guillen, et al. 2004). In addition to glucose, it has been reported that duodenal and jejunal infusions of lipids reduced ghrelin levels in rats and that infusion of amino acids also induced ghrelin suppression in rats (Overduin, et al. 2005). Although further studies are needed to elucidate the molecular mechanisms of ghrelin secretion from the stomach by nutrients, nutrients may be directly involved in the rapid decline of plasma ghrelin concentration after feeding.

Ghrelin secretion is regulated by peptide and steroid hormones. For example, ghrelin cells are located close to somatostatin-producing D cells, and somatostatin inhibits ghrelin secretion in rats and humans (Broglio, et al. 2002; Shimada, et al. 2003). Ghrelin secretion from the perfused stomach was also stimulated by glucagon treatment in a dose-dependent manner (Kamegai, et al. 2004), and this effect was shown to be mediated by glucagon receptors on ghrelin cells (Katayama, et al. 2007). de la Cour et al. found that epinephrine, norepinephrine, endothelin and secretin stimulated ghrelin release (de la Cour, et al. 2007). In addition, steroid hormone is involved in ghrelin regulation. In humans, estrogen regulates plasma ghrelin concentration (Paulo, et al. 2008) (Kellokoski, et al. 2005). In female rats, the levels of gastric ghrelin mRNA and plasma ghrelin and the number of ghrelin cells were found to be transiently increased by ovariectomy (Matsubara, et al. 2004), and treatment of gastric mucosal cells with estrogen showed that estrogen stimulated ghrelin expression and ghrelin secretion (Sakata, et al. 2006) (Zhao, et al. 2008). Recently, ghrelinproducing cell lines have been generated by different two groups. Iwakura et al. generated ghrelin cell lines from the stomach and showed that insulin decreased ghrelin secretion into culture medium (Iwakura, et al. 2010). Zhao et al. also established different ghrelin cell lines from the stomach and pancreas, and they showed that adrenaline and noradrenaline stimulated ghrelin secretion and that ghrelin-secreting cells express high levels of mRNA encoding beta(1)-adrenergic receptors (Zhao, et al. 2010). Moreover, they reported that fasting-induced increase in plasma ghrelin was blocked by treatment with reserpine to 
deplete adrenergic neurotransmitters from sympathetic neurons and that inhibition was also seen following administration of atenolol, a selective beta1-adrenergic antagonist, suggesting that sympathetic neurons are involved in ghrelin secretion by directly acting on beta1 receptors (Zhao et al. 2010).

\section{Conclusion and future perspectives}

Although ghrelin was discovered more than twenty years after motilin was identified, the biological and physiological functions of ghrelin have been studied in more detail than those of motilin. The major reason for this is due to the lack of a motilin gene in experimental rodents like mice and rats, which are used for biological and physiological analysis. So far, dogs and/or rabbits have been used for motilin studies, but these animals are too large to perform detailed analysis. Research has also been limited by the ban on use of genetically engineered mice. To resolve this problem and expand studies on motilin and its relationship with ghrelin, we established suncus as a novel motilin- and ghrelin-producing laboratory animal for motilin study. It has been shown that suncus motilin exerted phase III contraction in MMC using in vivo and in vitro experiments. This new suncus model will enable the detailed molecular and physiological analysis that were difficult using dogs and rabbits, and suncus will therefore be a powerful tool to understand the detailed mechanisms of motilinand/or ghrelin-induced gastrointestinal motility.

\section{References}

Ariyasu H, Takaya K, Tagami T, Ogawa Y, Hosoda K, Akamizu T, Suda M, Koh T, Natsui K, Toyooka S, et al. 2001 Stomach is a major source of circulating ghrelin, and feeding state determines plasma ghrelin-like immunoreactivity levels in humans. J Clin Endocrinol Metab 86 4753-4758.

Bado A, Levasseur S, Attoub S, Kermorgant S, Laigneau JP, Bortoluzzi MN, Moizo L, Lehy T, Guerre-Millo M, Le Marchand-Brustel Y, et al. 1998 The stomach is a source of leptin. Nature 394 790-793.

Banfield DK, MacGillivray RT, Brown JC \& McIntosh CH 1992 The isolation and characterization of rabbit motilin precursor cDNA. Biochim Biophys Acta 1131 341-344.

Bednarek MA, Feighner SD, Pong SS, McKee KK, Hreniuk DL, Silva MV, Warren VA, Howard AD, Van Der Ploeg LH \& Heck JV 2000 Structure-function studies on the new growth hormone-releasing peptide, ghrelin: minimal sequence of ghrelin necessary for activation of growth hormone secretagogue receptor 1a. J Med Chem 43 4370-4376.

Bolkent S, Yilmazer S, Kaya F \& Ozturk M 2001 Effects of acid inhibition on somatostatinproducing cells in the rat gastric fundus. Acta Histochem 103 413-422.

Bond CT, Nilaver G, Godfrey B, Zimmerman EA \& Adelman JP 1988 Characterization of complementary deoxyribonucleic acid for precursor of porcine motilin. Mol Endocrinol 2 175-180.

Broglio F, Gottero C, Prodam F, Destefanis S, Gauna C, Me E, Riganti F, Vivenza D, Rapa A, Martina V, et al. 2004 Ghrelin secretion is inhibited by glucose load and insulininduced hypoglycaemia but unaffected by glucagon and arginine in humans. Clin Endocrinol (Oxf) 61 503-509. 
Broglio F, Koetsveld Pv P, Benso A, Gottero C, Prodam F, Papotti M, Muccioli G, Gauna C, Hofland L, Deghenghi R, et al. 2002 Ghrelin secretion is inhibited by either somatostatin or cortistatin in humans. J Clin Endocrinol Metab 87 4829-4832.

Brown JC, Cook MA \& Dryburgh JR 1973 Motilin, a gastric motor activity stimulating polypeptide: the complete amino acid sequence. Can J Biochem 51 533-537.

Brown JC, Mutt V \& Dryburgh JR 1971 The further purification of motilin, a gastric motor activity stimulating polypeptide from the mucosa of the small intestine of hogs. Can J Physiol Pharmacol 49 399-405.

Cummings DE, Purnell JQ, Frayo RS, Schmidova K, Wisse BE \& Weigle DS 2001 A preprandial rise in plasma ghrelin levels suggests a role in meal initiation in humans. Diabetes 50 1714-1719.

Cummings DE, Weigle DS, Frayo RS, Breen PA, Ma MK, Dellinger EP \& Purnell JQ 2002 Plasma ghrelin levels after diet-induced weight loss or gastric bypass surgery. $N$ Engl J Med 346 1623-1630.

Dass NB, Munonyara M, Bassil AK, Hervieu GJ, Osbourne S, Corcoran S, Morgan M \& Sanger GJ 2003 Growth hormone secretagogue receptors in rat and human gastrointestinal tract and the effects of ghrelin. Neuroscience 120 443-453.

Date Y, Kojima M, Hosoda H, Sawaguchi A, Mondal MS, Suganuma T, Matsukura S, Kangawa K \& Nakazato M 2000 Ghrelin, a novel growth hormone-releasing acylated peptide, is synthesized in a distinct endocrine cell type in the gastrointestinal tracts of rats and humans. Endocrinology 141 4255-4261.

De Clercq P, Depoortere I, Macielag M, Vandermeers A, Vandermeers-Piret MC \& Peeters TL 1996 Isolation, sequence, and bioactivity of chicken motilin. Peptides 17 203-208.

de la Cour CD, Norlen P \& Hakanson R 2007 Secretion of ghrelin from rat stomach ghrelin cells in response to local microinfusion of candidate messenger compounds: a microdialysis study. Regul Pept 143 118-126.

Depoortere I, Van Assche G \& Peeters TL 1997 Distribution and subcellular localization of motilin binding sites in the rabbit brain. Brain Res 777 103-109.

Dornonville de la Cour C, Bjorkqvist M, Sandvik AK, Bakke I, Zhao CM, Chen D \& Hakanson R 2001 A-like cells in the rat stomach contain ghrelin and do not operate under gastrin control. Regul Pept 99 141-150.

Feighner SD, Tan CP, McKee KK, Palyha OC, Hreniuk DL, Pong SS, Austin CP, Figueroa D, MacNeil D, Cascieri MA, et al. 1999 Receptor for motilin identified in the human gastrointestinal system. Science 284 2184-2188.

Fujimiya M, Asakawa A, Ataka K, Chen CY, Kato I \& Inui A Ghrelin, des-acyl ghrelin, and obestatin: regulatory roles on the gastrointestinal motility. Int J Pept 2010.

Fujimiya M, Asakawa A, Ataka K, Kato I \& Inui A 2008 Different effects of ghrelin, des-acyl ghrelin and obestatin on gastroduodenal motility in conscious rats. World $J$ Gastroenterol 14 6318-6326.

Funakoshi A, Ho LL, Jen KL, Knopf R \& Vinik AI 1985 Diurnal profile of plasma motilin concentrations during fasting and feeding in man. Gastroenterol Jpn 20 446-456.

Funakoshi A, Matsumoto M, Sekiya K, Nakano I, Shinozaki H \& Ibayashi H 1983 Cholinergic independent dopaminergic regulation of motilin release in man. Gastroenterol Jpn 18 525-529.

Gnanapavan S, Kola B, Bustin SA, Morris DG, McGee P, Fairclough P, Bhattacharya S, Carpenter R, Grossman AB \& Korbonits M 2002 The tissue distribution of the 
mRNA of ghrelin and subtypes of its receptor, GHS-R, in humans. J Clin Endocrinol Metab 872988.

Guan XM, Yu H, Palyha OC, McKee KK, Feighner SD, Sirinathsinghji DJ, Smith RG, Van der Ploeg LH \& Howard AD 1997 Distribution of mRNA encoding the growth hormone secretagogue receptor in brain and peripheral tissues. Brain Res Mol Brain Res 48 23-29.

He J, Irwin DM, Chen R \& Zhang YP 2010 Stepwise loss of motilin and its specific receptor genes in rodents. J Mol Endocrinol 44 37-44.

Helmstaedter V, Kreppein W, Domschke W, Mitznegg P, Yanaihara N, Wunsch E \& Forssmann WG 1979 Immunohistochemical localization of motilin in endocrine non-enterochromaffin cells of the small intestine of humans and monkey. Gastroenterology 76 897-902.

Howard AD, Feighner SD, Cully DF, Arena JP, Liberator PA, Rosenblum CI, Hamelin M, Hreniuk DL, Palyha OC, Anderson J, et al. 1996 A receptor in pituitary and hypothalamus that functions in growth hormone release. Science 273 974-977.

Ishida Y, Sakahara S, Tsutsui C, Kaiya H, Sakata I, Oda S \& Sakai T 2009 Identification of ghrelin in the house musk shrew (Suncus murinus): cDNA cloning, peptide purification and tissue distribution. Peptides 30 982-990.

Itoh Z, Takeuchi S, Aizawa I, Mori K, Taminato T, Seino Y, Imura H \& Yanaihara N 1978 Changes in plasma motilin concentration and gastrointestinal contractile activity in conscious dogs. Am J Dig Dis 23 929-935.

Iwakura H, Li Y, Ariyasu H, Hosoda H, Kanamoto N, Bando M, Yamada G, Hosoda K, Nakao K, Kangawa K, et al. 2010 Establishment of a novel ghrelin-producing cell line. Endocrinology 151 2940-2945.

Kageyama H, Funahashi H, Hirayama M, Takenoya F, Kita T, Kato S, Sakurai J, Lee EY, Inoue S, Date Y, et al. 2005 Morphological analysis of ghrelin and its receptor distribution in the rat pancreas. Regul Pept 126 67-71.

Kaiya H, Kodama S, Ishiguro K, Matsuda K, Uchiyama M, Miyazato M \& Kangawa K 2009 Ghrelin-like peptide with fatty acid modification and O-glycosylation in the red stingray, Dasyatis akajei. BMC Biochem 1030.

Kaiya H, Kojima M, Hosoda H, Koda A, Yamamoto K, Kitajima Y, Matsumoto M, Minamitake Y, Kikuyama S \& Kangawa K 2001 Bullfrog ghrelin is modified by noctanoic acid at its third threonine residue. J Biol Chem $27640441-40448$.

Kaiya H, Kojima M, Hosoda H, Moriyama S, Takahashi A, Kawauchi H \& Kangawa K 2003 Peptide purification, complementary deoxyribonucleic acid (DNA) and genomic DNA cloning, and functional characterization of ghrelin in rainbow trout. Endocrinology 144 5215-5226.

Kaiya H, Sakata I, Kojima M, Hosoda H, Sakai T \& Kangawa K 2004 Structural determination and histochemical localization of ghrelin in the red-eared slider turtle, Trachemys scripta elegans. Gen Comp Endocrinol 138 50-57.

Kaiya H, Sakata I, Yamamoto K, Koda A, Sakai T, Kangawa K \& Kikuyama S 2006 Identification of immunoreactive plasma and stomach ghrelin, and expression of stomach ghrelin mRNA in the bullfrog, Rana catesbeiana. Gen Comp Endocrinol 148 236-244.

Kaiya H, Van Der Geyten S, Kojima M, Hosoda H, Kitajima Y, Matsumoto M, Geelissen S, Darras VM \& Kangawa K 2002 Chicken ghrelin: purification, cDNA cloning, and biological activity. Endocrinology 143 3454-3463. 
Kamegai J, Tamura H, Shimizu T, Ishii S, Sugihara H \& Oikawa S 2001 Regulation of the ghrelin gene: growth hormone-releasing hormone upregulates ghrelin mRNA in the pituitary. Endocrinology 142 4154-4157.

Kamegai J, Tamura H, Shimizu T, Ishii S, Sugihara H \& Oikawa S 2004 Effects of insulin, leptin, and glucagon on ghrelin secretion from isolated perfused rat stomach. Regul Pept 119 77-81.

Katayama T, Shimamoto S, Oda H, Nakahara K, Kangawa K \& Murakami N 2007 Glucagon receptor expression and glucagon stimulation of ghrelin secretion in rat stomach. Biochem Biophys Res Commun 357 865-870.

Kellokoski E, Poykko SM, Karjalainen AH, Ukkola O, Heikkinen J, Kesaniemi YA \& Horkko S 2005 Estrogen replacement therapy increases plasma ghrelin levels. J Clin Endocrinol Metab 90 2954-2963.

Khan N, Graslund A, Ehrenberg A \& Shriver J 1990 Sequence-specific 1H NMR assignments and secondary structure of porcine motilin. Biochemistry 29 5743-5751.

Kojima M, Hosoda H, Date Y, Nakazato M, Matsuo H \& Kangawa K 1999 Ghrelin is a growth-hormone-releasing acylated peptide from stomach. Nature 402 656-660.

Kojima M, Ida T \& Sato T 2008 Structure of mammalian and nonmammalian ghrelins. Vitam Horm 77 31-46.

Ku SK, Lee HS \& Lee JH 2004 An immunohistochemical study of gastrointestinal endocrine cells in the BALB/c mouse. Anat Histol Embryol 33 42-48.

Matsubara M, Sakata I, Wada R, Yamazaki M, Inoue K \& Sakai T 2004 Estrogen modulates ghrelin expression in the female rat stomach. Peptides 25 289-297.

McKee KK, Tan CP, Palyha OC, Liu J, Feighner SD, Hreniuk DL, Smith RG, Howard AD \& Van der Ploeg LH 1997 Cloning and characterization of two human G proteincoupled receptor genes (GPR38 and GPR39) related to the growth hormone secretagogue and neurotensin receptors. Genomics 46 426-434.

Miura T, Maruyama K, Kaiya H, Miyazato M, Kangawa K, Uchiyama M, Shioda S \& Matsuda K 2009 Purification and properties of ghrelin from the intestine of the goldfish, Carassius auratus. Peptides 30 758-765.

Miyamoto Y \& Miyamoto M 2004 Immunohistochemical localizations of secretin, cholecystokinin, and somatostatin in the rat small intestine after acute cisplatin treatment. Exp Mol Pathol 77 238-245.

Mondal MS, Date Y, Yamaguchi H, Toshinai K, Tsuruta T, Kangawa K \& Nakazato M 2005 Identification of ghrelin and its receptor in neurons of the rat arcuate nucleus. Regul Pept 126 55-59.

Ohshiro H, Nonaka M \& Ichikawa K 2008 Molecular identification and characterization of the dog motilin receptor. Regul Pept 146 80-87.

Overduin J, Frayo RS, Grill HJ, Kaplan JM \& Cummings DE 2005 Role of the duodenum and macronutrient type in ghrelin regulation. Endocrinology 146 845-850.

Paulo RC, Brundage R, Cosma M, Mielke KL, Bowers CY \& Veldhuis JD 2008 Estrogen elevates the peak overnight production rate of acylated ghrelin. J Clin Endocrinol Metab 93 4440-4447.

Poitras P, Dumont A, Cuber JC \& Trudel L 1993 Cholinergic regulation of motilin release from isolated canine intestinal cells. Peptides 14 207-213.

Rozengurt N, Wu SV, Chen MC, Huang C, Sternini C \& Rozengurt E 2006 Colocalization of the alpha-subunit of gustducin with PYY and GLP-1 in L cells of human colon. Am J Physiol Gastrointest Liver Physiol 291 G792-802. 
Sakahara S, Xie Z, Koike K, Hoshino S, Sakata I, Oda S, Takahashi T \& Sakai T 2010 Physiological characteristics of gastric contractions and circadian gastric motility in the free-moving conscious house musk shrew (Suncus murinus). Am J Physiol Regul Integr Comp Physiol 299 R1106-1113.

Sakai T, Satoh M, Koyama H, Iesaki K, Umahara M, Fujikura K \& Itoh Z 1994a Localization of motilin-immunopositive cells in the rat intestine by light microscopic immunocytochemistry. Peptides 15 987-991.

Sakai T, Satoh M, Sonobe K, Nakajima M, Shiba Y \& Itoh Z 1994b Autoradiographic study of motilin binding sites in the rabbit gastrointestinal tract. Regul Pept 53 249-257.

Sakata I, Nakamura K, Yamazaki M, Matsubara M, Hayashi Y, Kangawa K \& Sakai T 2002 Ghrelin-producing cells exist as two types of cells, closed- and opened-type cells, in the rat gastrointestinal tract. Peptides 23 531-536.

Sakata I, Tanaka T, Yamazaki M, Tanizaki T, Zheng Z \& Sakai T 2006 Gastric estrogen directly induces ghrelin expression and production in the rat stomach. J Endocrinol 190 749-757.

Satoh M, Sakai T, Koyama H, Shiba Y \& Itoh Z 1995 Immunocytochemical localization of motilin-containing cells in the rabbit gastrointestinal tract. Peptides 16 883-887.

Shimada M, Date Y, Mondal MS, Toshinai K, Shimbara T, Fukunaga K, Murakami N, Miyazato M, Kangawa K, Yoshimatsu H, et al. 2003 Somatostatin suppresses ghrelin secretion from the rat stomach. Biochem Biophys Res Commun 302 520-525.

Soriano-Guillen L, Barrios V, Martos G, Chowen JA, Campos-Barros A \& Argente J 2004 Effect of oral glucose administration on ghrelin levels in obese children. Eur J Endocrinol 151 119-121.

Strausberg RL, Feingold EA, Grouse LH, Derge JG, Klausner RD, Collins FS, Wagner L, Shenmen CM, Schuler GD, Altschul SF, et al. 2002 Generation and initial analysis of more than 15,000 full-length human and mouse cDNA sequences. Proc Natl Acad Sci U S A 99 16899-16903.

Tack J, Depoortere I, Bisschops R, Delporte C, Coulie B, Meulemans A, Janssens J \& Peeters $\mathrm{T} 2006$ Influence of ghrelin on interdigestive gastrointestinal motility in humans. Gut 55 327-333.

Takeshita E, Matsuura B, Dong M, Miller LJ, Matsui H \& Onji M 2006 Molecular characterization and distribution of motilin family receptors in the human gastrointestinal tract. J Gastroenterol 41 223-230.

Taniguchi H, Ariga H, Zheng J, Ludwig K \& Takahashi T 2008 Effects of ghrelin on interdigestive contractions of the rat gastrointestinal tract. World J Gastroenterol 14 6299-6302.

Ter Beek WP, Muller ES, van den Berg M, Meijer MJ, Biemond I \& Lamers CB 2008 Motilin receptor expression in smooth muscle, myenteric plexus, and mucosa of human inflamed and noninflamed intestine. Inflamm Bowel Dis 14 612-619.

Theodorakis MJ, Carlson O, Michopoulos S, Doyle ME, Juhaszova M, Petraki K \& Egan JM 2006 Human duodenal enteroendocrine cells: source of both incretin peptides, GLP-1 and GIP. Am J Physiol Endocrinol Metab 290 E550-559.

Toshinai K, Mondal MS, Nakazato M, Date Y, Murakami N, Kojima M, Kangawa K \& Matsukura S 2001 Upregulation of Ghrelin expression in the stomach upon fasting, insulin-induced hypoglycemia, and leptin administration. Biochem Biophys Res Commun 281 1220-1225. 
Tsutsui C, Kajihara K, Yanaka T, Sakata I, Itoh Z, Oda S \& Sakai T 2009 House musk shrew (Suncus murinus, order: Insectivora) as a new model animal for motilin study. Peptides 30 318-329.

Vantrappen G, Janssens J, Peeters TL, Bloom SR, Christofides ND \& Hellemans J 1979 Motilin and the interdigestive migrating motor complex in man. Dig Dis Sci 24 497500.

Volante M, Allia E, Gugliotta P, Funaro A, Broglio F, Deghenghi R, Muccioli G, Ghigo E \& Papotti M 2002 Expression of ghrelin and of the GH secretagogue receptor by pancreatic islet cells and related endocrine tumors. J Clin Endocrinol Metab 87 13001308.

Wada R, Sakata I, Kaiya H, Nakamura K, Hayashi Y, Kangawa K \& Sakai T 2003 Existence of ghrelin-immunopositive and -expressing cells in the proventriculus of the hatching and adult chicken. Regul Pept 111 123-128.

Wang YN, McDonald JK \& Wyatt RJ 1987 Immunocytochemical localization of neuropeptide Y-like immunoreactivity in adrenergic and non-adrenergic neurons of the rat gastrointestinal tract. Peptides 8 145-151.

Wierup N, Bjorkqvist M, Westrom B, Pierzynowski S, Sundler F \& Sjolund K 2007 Ghrelin and motilin are cosecreted from a prominent endocrine cell population in the small intestine. J Clin Endocrinol Metab 92 3573-3581.

Xu L, Depoortere I, Tang M \& Peeters TL 2001 Identification and expression of the motilin precursor in the guinea pig. FEBS Lett 490 7-10.

Xu L, Depoortere I, Thielemans L, Huang Z, Tang M \& Peeters TL 2003 Sequence, distribution and quantification of the motilin precursor in the cat. Peptides 24 1387-1395.

Xu L, Depoortere I, Tomasetto C, Zandecki M, Tang M, Timmermans JP \& Peeters TL 2005 Evidence for the presence of motilin, ghrelin, and the motilin and ghrelin receptor in neurons of the myenteric plexus. Regul Pept 124 119-125.

Yamamoto I, Kaiya H, Tsutsui C, Sakai T, Tsukada A, Miyazato M \& Tanaka M 2008 Primary structure, tissue distribution, and biological activity of chicken motilin receptor. Gen Comp Endocrinol 156 509-514.

Zhao TJ, Sakata I, Li RL, Liang G, Richardson JA, Brown MS, Goldstein JL \& Zigman JM 2010 Ghrelin secretion stimulated by \{beta\}1-adrenergic receptors in cultured ghrelinoma cells and in fasted mice. Proc Natl Acad Sci U S A 107 15868-15873.

Zhao Z, Sakata I, Okubo Y, Koike K, Kangawa K \& Sakai T 2008 Gastric leptin, but not estrogen and somatostatin, contributes to the elevation of ghrelin mRNA expression level in fasted rats. J Endocrinol 196 529-538.

Zheng J, Ariga H, Taniguchi H, Ludwig K \& Takahashi T 2009 Ghrelin regulates gastric phase III-like contractions in freely moving conscious mice. Neurogastroenterol Motil $2178-84$.

Zietlow A, Nakajima H, Taniguchi H, Ludwig K \& Takahashi T 2010 Association between plasma ghrelin and motilin levels during MMC cycle in conscious dogs. Regul Pept 164 78-82.

Zigman JM, Jones JE, Lee CE, Saper CB \& Elmquist JK 2006 Expression of ghrelin receptor mRNA in the rat and the mouse brain. J Comp Neurol 494 528-548. 


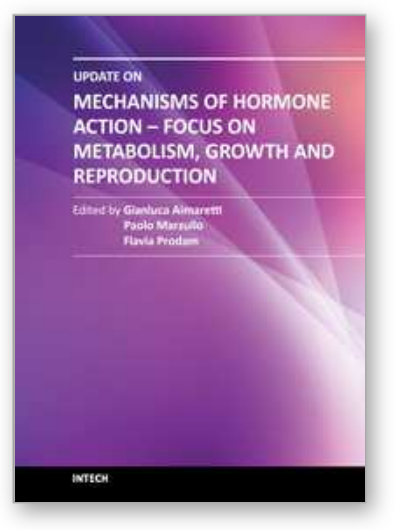

\section{Update on Mechanisms of Hormone Action - Focus on Metabolism, Growth and Reproduction}

Edited by Prof. Gianluca Aimaretti

ISBN 978-953-307-341-5

Hard cover, 470 pages

Publisher InTech

Published online 26, October, 2011

Published in print edition October, 2011

The purpose of the present volume is to focus on more recent aspects of the complex regulation of hormonal action, in particular in 3 different hot fields: metabolism, growth and reproduction. Modern approaches to the physiology and pathology of endocrine glands are based on cellular and molecular investigation of genes, peptide, hormones, protein cascade at different levels. In all of the chapters in the book all, or at least some, of these aspects are described in order to increase the endocrine knowledge.

\section{How to reference}

In order to correctly reference this scholarly work, feel free to copy and paste the following:

Ichiro Sakata and Takafumi Sakai (2011). The Gut Peptide Hormone Family, Motilin and Ghrelin, Update on Mechanisms of Hormone Action - Focus on Metabolism, Growth and Reproduction, Prof. Gianluca Aimaretti (Ed.), ISBN: 978-953-307-341-5, InTech, Available from: http://www.intechopen.com/books/update-onmechanisms-of-hormone-action-focus-on-metabolism-growth-and-reproduction/the-gut-peptide-hormonefamily-motilin-and-ghrelin

\section{INTECH}

open science | open minds

\section{InTech Europe}

University Campus STeP Ri

Slavka Krautzeka 83/A

51000 Rijeka, Croatia

Phone: +385 (51) 770447

Fax: +385 (51) 686166

www.intechopen.com

\section{InTech China}

Unit 405, Office Block, Hotel Equatorial Shanghai

No.65, Yan An Road (West), Shanghai, 200040, China

中国上海市延安西路65号上海国际贵都大饭店办公楼 405 单元

Phone: +86-21-62489820

Fax: $+86-21-62489821$ 
(C) 2011 The Author(s). Licensee IntechOpen. This is an open access article distributed under the terms of the Creative Commons Attribution 3.0 License, which permits unrestricted use, distribution, and reproduction in any medium, provided the original work is properly cited. 